\title{
Hair Cells and Supporting Cells Share a Common Progenitor in the Avian Inner Ear
}

\author{
Donna M. Fekete, ${ }^{1}$ Shanthini Muthukumar, ${ }^{2}$ and Domna Karagogeos ${ }^{3}$ \\ ${ }^{1}$ Department of Biological Sciences, Purdue University, West Lafayette, Indiana 47907, 2Department of Biology, Boston \\ College, Chestnut Hill, Massachusetts 02167, and '3Department of Basic Sciences, University of Crete Medical School, \\ Heraklion 711 10, Crete, and the Institute for Molecular Biology and Biotechnology, Heraklion, Crete, Greece
}

\begin{abstract}
Sensory organs of the vertebrate inner ear contain two major cell types: hair cells (HCs) and supporting cells (SCs). To study the lineage relationships between these two populations, replication-defective retroviral vectors encoding marker genes were delivered to the otic vesicle of the chicken embryo. The resulting labeled clones were analyzed in the hearing organ of the chicken, called the basilar papilla (BP), after cellular differentiation. BPs were allowed to develop for 2 weeks after delivery of the retrovirus, were removed, and were processed histochemically as whole mounts to identify clones of cells. Clusters of labeled cells were evident in the sensory epithelium, the nonsensory epithelium, and in adjacent tissues. Labeled cell types included HCs, two morphologically distinct types of
\end{abstract}

Mechanosensory organs of the inner ear are involved in the detection of hearing and balance in vertebrates. Typically, these organs contain two major types of epithelial cells: hair cells (HCs), which are the mechanosensory cells, and supporting cells (SCs), which can vary tremendously in structure and function. How these cell types are specified from the simple epithelium of the early otic vesicle is not known (Fekete, 1996).

The loss of sensory cells in hearing organs, either congenitally or pathologically, causes hearing loss with a severity that correlates with the extent of missing HCs. In the mature mammalian organ of Corti, the HCs are not replaced, and the deficits are permanent. In contrast, in the bird basilar papilla (BP; the functional homolog of the organ of Corti), the HCs can regenerate (Cotanche and Lee, 1994). This regeneration is accompanied by recovery of function both behaviorally (Dooling et al., 1997) and physiologically (Girod et al., 1991; Muller et al., 1997). The reappearance of $\mathrm{HCs}$ is preceded by renewed mitosis in the sensory epithelium; the mitotic pool of cells gives rise to new $\mathrm{HCs}$ and SCs (Cotanche, 1987; Corwin and Cotanche, 1988; Ryals and Rubel, 1988; Girod et al., 1989; Duckert and Rubel, 1993; Stone and Cotanche, 1994). There is also evidence that HCs can arise

\footnotetext{
Received May 20, 1998; revised July 7, 1998; accepted July 13, 1998.

This work was supported by a grant from the National Institutes of Health, a Clare Booth Luce Professorship, and a Basil O'Connor Scholarship grant from the March of Dimes Birth Defects Foundation to D.M.F., and by the Fulbright Foundation and the Human Frontiers Program (D.K.). We are especially grateful to Bradlee Drabant, Nirali Desai, and Marielle Langlois for conducting the PCR-sequencing experiments. Guy Richardson, Amy Kiernan, and Michele Bever provided valuable critiques of this manuscript. We thank Connie Cepko and Shawn Fields-Berry for the generous gift of CHAPOL plasmid DNA, and Jeff Golden for guidance in PCR sequencing.

Correspondence should be addressed to Donna M. Fekete, Department of Biological Sciences, Lilly Hall, Purdue University, West Lafayette, IN 47907.

Copyright (C) 1998 Society for Neuroscience 0270-6474/98/187811-11\$05.00/0
}

SCs, homogene cells, border cells, hyaline cells, ganglion cells, and connective tissue cells. Each clone was sectioned and cell-type identification was performed on sensory clones expressing retrovirally transduced $\beta$-galactosidase. Cell composition was determined for 41 sensory clones, most of which contained both HCs and SCs. Clones containing one $\mathrm{HC}$ and one SC were observed, suggesting that a common progenitor exists that can remain bipotential up to its final mitotic division. The possibility that these two cell types may also arise from a mitotic precursor during $\mathrm{HC}$ regeneration in the mature basilar papilla is consistent with their developmental history.

Key words: inner ear; basilar papilla; cochlea; ear development; cell lineage; sensory cell; retrovirus from the transdifferentiation of SCs, without an intermediate mitosis, in the axolotl lateral line, in the bird BP, and in mammalian vestibular organs (Jones and Corwin, 1996; Adler and Raphael, 1996; Li and Forge, 1997; Adler et al., 1997). Although it is often assumed that both cell types are generated from a common pool of precursors during regeneration (for discussion, see Corwin et al., 1991), direct observation or single-cell labeling of individual cells is required to show that this is indeed the case. This has been unequivocally demonstrated in the regenerating lateral line of the axolotl by following SCs that were induced to divide after laser ablation of HCs. Single progenitor cells followed in time-lapse microscopy divided to give rise to an $\mathrm{HC}$ and an SC (Jones and Corwin, 1996). Such direct lineage tracing has not yet been applied to a mature vertebrate inner ear undergoing $\mathrm{HC}$ regeneration.

One can ask whether HCs and SCs share a common progenitor during development as a prelude to understanding how new HCs might arise during regeneration (Corwin and Oberholtzer, 1997). Like the regenerating organ, in development $\mathrm{HCs}$ and SCs are generated concurrently (Katayama and Corwin, 1989). Both cell types come out of division between embryonic day 5 (E5) and E8 in the chicken BP. There is also a spatial correspondence in cell birthdays, progressing from superior-proximal to inferior-distal for both HCs and SCs (Katayama and Corwin, 1989). This has led to the proposal that the two cell types may share a common progenitor cell in development (for review, see Corwin et al., 1993).

In this study we used lineage analysis to address this question directly. Replication-defective retroviral vectors were used to label a few progenitor cells on the BP near the time of the last few cell divisions. The results showed that the vast majority of the clones contained both HCs and SCs. Five clones consisting of one 
HC and one SC were observed. These data demonstrate that the two cell types share a common progenitor in the developing $\mathrm{BP}$, and that the progenitor probably remains bipotential up to its final mitotic division. This finding has important implications for investigations into the potential source or sources of $\mathrm{HCs}$ during regeneration.

\section{MATERIALS AND METHODS}

Preparation of retroviral stocks. The vectors used in this study were replication-defective retroviruses that carry genes encoding histochemically detectable markers. The RDlac vector was a conventional replication-defective virus containing $\beta$-galactosidase. In contrast, chicken alkaline phosphatase library (CHAPOL) stocks consist of a library of viruses that contain $2.6 \times 10^{6}$ different viral genomes, each of which has a 24 bp variable tag $(\mathrm{G} / \mathrm{C}-\mathrm{A} / \mathrm{T})_{12}$ that can be amplified and sequenced by PCR (Golden et al., 1995) in addition to encoding human placental alkaline phosphatase (AP).

Plasmid DNA for RDlac1 (a kind gift of Andy Stoker, Oxford University) was transfected into the quail packaging line, Q2bn (Stoker and Bissell, 1988) using calcium phosphate-glycerol shock, and supernatant from the cells was harvested after $1-2 \mathrm{~d}$ and concentrated by centrif $\mathrm{u}-$ gation to generate viral stocks as described (Fekete et al., 1994). The titer of the concentrated stock was $2.4 \times 10^{6}$ infectious units $/ \mathrm{ml}$ (i.u./ml).

The pCHAPOL plasmid (provided by Fields-Berry and Cepko, Harvard Medical School) came from the same plasmid preparation which, after transfection into Q2bn cells, generated a library with $>10^{5}$ different viral genomes, based on sampling $>250$ independent clones (Golden et al., 1995; Golden and Cepko, 1996). These data assure that the plasmid DNA did not contain significant over-representation of individual members of the library. In the present study, transfection of pCHAPOL into Q2bn cells was used to generate a new CHAPOL viral stock. In principle, virus production can also introduce unequal amplification of different viral sequences and must be characterized independently. In fact, two sequences appeared to be over-represented in this library, as described below. Concentration by centrifugation yielded a stock with a titer of $6.2 \times 10^{6}$ i.u./ml when thawed immediately. The same stock was thawed 3 years later and gave a titer of $2 \times 10^{6}$ i.u./ml. Nearly all of the infections were performed within 2 months after the stock was generated. A standard "helper" test (Cepko, 1992) was performed to confirm the absence of contaminating replication-competent virus.

Chicken embryos and primary cells. Unincubated, fertilized white Leghorn chicken eggs were obtained from SPAFAS, Inc. (Norwich, CT) and used for in ovo injections. Primary cultures of chicken embryo fibroblasts (CEFs) were made from one to four line 0 embryos (USDA Poultry Research Laboratory, East Lansing, MI) at E10 and frozen using published procedures (Morgan and Fekete, 1996). All cells were grown in chick culture media (10\% FCS and $2 \%$ chicken serum in DMEM) and detached from the plates using trypsin digestion for passaging.

Injecting viruses into the inner ear. The detailed protocols for storage and preparation of the eggs, and preparation of the injection pipettes have been published (Morgan and Fekete, 1996). Briefly, a hole was cut through the egg shell, the embryos were exposed, and pulled glass capillary tubes with tip diameters of $10-20 \mu \mathrm{m}$ were used to deliver $\sim 0.1$ $\mu \mathrm{l}$ of virus to the otic vesicle at stages ranging from E17 to E29 (Hamburger and Hamilton, 1951). The mean age at the time of virus injection was stage $23.3 \pm 2.6(\mathrm{SD})$ for CHAPOL injections and stage $22.2 \pm 2.7$ for RDlac injections. Specimens that received virus injections on the same day were given the same alphanumeric batch designation (e.g., K9), followed by a hyphen and a sequential specimen number.

Histology. Tissue was fixed in phosphate-buffered $4 \%$ paraformaldehyde (AP histochemistry) or in phosphate-buffered $0.2-0.5 \%$ glutaraldehyde with or without $2 \%$ paraformaldehye (for $\beta$-galactosidase histochemistry) overnight. For specimens processed on E6-E11, the tissue was rinsed with PBS, processed through 10, 20, and 30\% sucrose in PBS, embedded in $7.5 \%$ gelatin and $15 \%$ sucrose in PBS, frozen using liquid nitrogen, and sectioned on a Reichart cryostat at $35 \mu \mathrm{m}$. Slides were processed for $\beta$-galactosidase histochemistry or AP histochemistry as described (Fekete and Cepko, 1993).

Specimens processed on E18-E20 were prepared as whole-mount preparations of the BP. The middle ear was exposed, the columella removed, and the head placed in fixative, usually for overnight. The bone surrounding the injected ear (typically the right side) was removed with fine forceps, the BP with attached tissue (including the lagena) was isolated, and the tegmentum vasculosum was removed. These whole- mount preparations were processed intact for detection of the histochemical markers, with incubation times that varied from 2-6 hr. Specimens were stored in PBS at $4^{\circ} \mathrm{C}$. Each specimen was traced with a drawing tube attached to a Wild dissection microscope. The position of each labeled cluster was recorded on the drawing, and each was given a unique letter (sensory clusters) or number (nonsensory clusters) for later analysis. The specimens were then processed either for paraffin-embedding or for gelatin-embedding. Sections were cut either with a rotary microtome, a vibratome, or a cryostat. The latter was preferred because fewer samples were lost during tissue processing, whereas sections thin enough for analysis of cell types were still provided.

Analysis of infected cells. Of the 115 embryos that survived to E18-E20 after injections of CHAPOL, 68 (59\%) showed evidence of at least one cluster of labeled cells of either the sensory or nonsensory category. Fifty-two (45\%) of the specimens had at least one sensory cluster, and 52 $(45 \%)$ had at least one nonsensory cluster. Because a variable amount of nonsensory tissue was removed, counts of the nonsensory clusters were likely to be underestimated. Ears infected with RDlac that survived to E11 $(n=11)$ or E18-E19 $(n=44)$ showed evidence of at least one $\beta$-galactosidase-positive cluster in $36(65 \%)$ specimens. At least one sensory cluster was evident in $31(56 \%)$ of the ears, whereas $30(55 \%)$ had at least one nonsensory cluster. Thus, the in vivo infection rates of the two viral stocks appeared similar, although the titer of CHAPOL was calculated to be $\sim 2.5$-fold higher than the titer of RDlac. It is difficult to know whether the apparent discrepancy between the in vitro titers and the in vivo infection efficiencies implies some underlying problem with CHAPOL (such as excess nonexpressing clones) or a higher efficiency of integration for RDlac (perhaps because it was a smaller genome). Differences in the experimenters performing the titers and the injections, and quantitative differences in stages of the embryos at the time of injection for the two stocks, make such comparisons tenuous.

Individual clones were identified from serial sections and examined under Nomarski optics to determine the constituent cell types. Clonal composition was only performed on clones for which no sections were missing on either side of the labeled profiles, and in which the crosssectional orientation of the BP made nuclear location unambiguous. Because the papilla is strongly curved at its apical end, some of the apical clones could not be analyzed because of the tangential nature of the resulting sections. For some AP-positive clones, the coverslip was removed, and the slide was incubated with $1.25 \mu \mathrm{g} / \mathrm{ml}$ Hoescht dye 33258 (bisbenzimide) to label nuclei and/or immunostained for HCA, an antigen located on the apical surfaces of HCs (Richardson et al., 1990; Bartolami et al., 1991). Cell-type identification was less ambiguous with $\beta$-galactosidase in comparison to AP, and so the quantitative analysis of clonal composition was performed exclusively from RDlac-infected ears. However, both viral stocks were useful for a statistical analysis of clonality, because in each case clones were readily apparent from the surface views of the tissue.

PCR amplification and sequencing of viral genomes. Protocols for the amplification of viral DNA from single cells or small clusters of cells have been described (Golden et al., 1995). Briefly, the coverslips were removed, and labeled cells were identified using a Wild dissection microscope. Labeled cells and some surrounding negative tissue were picked from the sections using sterile razor blades and were dropped into a proteinase K digestion solution. As a negative control, after removing the labeled cells from a section, the remainder of the unlabeled otic epithelium was sampled separately as a "negative pick". Adjacent sections were also used as AP-negative picks. Thus, in most cases, the negative picks consisted of considerably larger tissue chunks than the positive picks. All samples were digested with proteinase $\mathrm{K}$ for $2 \mathrm{hr}$. Using primer pairs (outer, CHAP-0 and CHAP-5; inner, CHAP-2 and CHAP-3) that react with CHAPOL (Golden et al., 1995), two rounds of fully nested PCR amplifications were used to generate a $121 \mathrm{bp}$ product. A $1 \mu \mathrm{l}$ aliquot of this product was used as the template, and CHAP-3 oligonucleotide was used as the primer in ${ }^{35} \mathrm{~S}$, PCR-based sequencing reactions using a commercial kit (Cyclist Exo-Pfu DNA sequencing kit; Stratagene, La Jolla, CA). The bands were separated on a sequencing gel and detected by exposing x-ray film for 3-5 d.

PCR-based contamination was frequently encountered in early experiments; in some cases it was determined that the contaminating sequence derived from a single member of the library that was subcloned and used as a positive control. Alterations in the PCR amplification reaction (longer annealing time with fewer cycles) were successful in eliminating most of this problem. PCR amplification was predicted to generate a 121 bp product. Experiments in which water controls came up positive for the 
121 bp product were suspected of having PCR contamination, and all other samples from the same run were eliminated to avoid false-positive results. There were a total of nine independent PCR runs that were judged to be free of external contamination. From these, a total of 86 picks were analyzed from AP-positive areas and 17 picks from APnegative areas. The predicted 121 bp product was obtained from $50 \%$ of the AP-positive picks $(n=43)$ and $24 \%$ of the AP-negative picks $(n=$ 4). Readable DNA sequence information was obtained from only a subset of samples that had a detectable PCR product $(n=30)$. There were an additional nine samples that appeared to have at least two different sequences and were judged uninterpretable. Two sequences appeared to be over-represented in the library: sequence 13 was observed in three embryos, and sequence 12 was observed in two embryos, including two different clones from the same ear. Because of the ambiguity inherent in over-represented sequences, no conclusions were drawn from picks yielding either of the two sequences.

\section{RESULTS}

This study was aimed at the identification, spatial distribution, and composition of clonally related cells in the chicken BP during the period of HC genesis. The major focus was on the sensory clones of the BP, although some details of nonsensory clones were also revealed. Infection with replication-defective viruses was used to label individual progenitor cells in the otic epithelium 1-4 d before the final mitotic divisions of HCs and SCs, on E3.5-E5. The viral genome will have been inherited by one of the two daughter cells of an infected cell after its next mitotic division (Roe et al., 1993). The lineage of each infected cell was then analyzed by waiting until the mitotic phase was over and any resulting progeny had differentiated. The quantitative data were generated from two different virus-injected pools: 115 ears injected with CHAPOL, a library of viruses encoding human placental AP as a marker gene, and 55 ears injected with RDlac, a virus encoding $\beta$-galactosidase.

\section{Morphology of infected BPs}

Spatially isolated cells or cell clusters were observed in both the sensory and nonsensory parts of the tissue when viewed as whole mounts of the BP (Fig. $1 A-C$ ). Clusters expressing $\beta$-galactosidase were morphologically identical to clusters expressing AP at the resolution of the dissection microscope. The major structures and locations of different cell types are indicated in Figure $1 D$. In the descriptions that follow, the nomenclature of Oesterle and Rubel (1993) has been adopted whereby "sensory cells" will refer to all epithelial cell types residing on the BP proper, including HCs and sensory SCs. "Nonsensory cells" will refer only to those epithelial cell types immediately adjacent to the sensory cells, including the homogene cells on the superior edge and the border, hyaline and cuboidal cells on the inferior edge (Oesterle et al., 1992; Oesterle and Rubel, 1993). Other nonsensory cells labeled by retrovirus injection included statoacoustic ganglion neurons, fibroblasts of the basilar membrane, and connective tissue cells of the superior and inferior fibrocartilagenous plates. Additional labeled cells were also observed in the tegmentum vasculosum before it was removed.

\section{Morphology of labeled nonsensory and nonepithelial cells}

The most obvious nonsensory cells labeled with both retroviruses were the tall columnar cells on the neural side of the organ, called homogene cells, to which the tectorial membrane attaches on its neural edge. Homogene cells were found in $38 \%$ of CHAPOLinfected and $72 \%$ of RDlac-infected BPs that were processed as whole mounts (examples can be seen in Fig. $1 B$, clone 1 and Fig. $1 C$, clones 1,2). These cells were usually clustered into several columns separated by unlabeled cells (Fig. 1E). Although one or two clusters were the norm, arrays of up to six regularly spaced clusters could be found dispersed longitudinally along the BP. It was difficult to know whether such an array represented a single clone or multiple clones, but the regular spacing suggested that the cells may have been derived from a single progenitor that migrated longitudinally, giving off progeny along the way.

On the abneural edge of the BP, cells were identified based on the criterion of Oesterle et al. (1992). Labeled border cells were occasionally observed (data not shown), whereas hyaline cells were labeled more frequently (Fig. $1 F$ ). The latter clones occurred either as single tight clusters of one to four cells or multiple clusters separated by unlabeled cells. In two cases (of a total of 195 sensory clones), both border cells and hyaline cells were so close to labeled SCs that they were included in the same clone. One of these ears received virus at stage 19.5 and the other at stage 20 . These data suggest that the boundary between the sensory and nonsensory epithelium may not be firmly established until after stage 20 (considering the presumed delay to viral integration, see Discussion).

Labeled cells were frequently observed in the statoacoustic ganglion. In CHAPOL-infected tissue, the peripheral processes of these cells could sometimes be followed to the base of the HCs (Fig. $1 H$, arrow). When present, cells with neuronal morphology were found as cohorts of $\sim 5-10$ cells dispersed across a series of sections (Fig. $1 I-J$ ), suggesting that clonally related cells spread out within the ganglion.

Fibrocartilagenous cells were also abundant in some ears. Usually they were dispersed more widely than either the sensory or nonsensory epithelial clones. Labeled fibroblastic cells beneath the sensory epithelium were obvious when the epithelium was cut tangentially (Fig. 1G). However, because these cells were difficult to see in whole mounts, and because they presented very small profiles in cross-section that were only weakly labeled by AP, they were easily overlooked.

Because the viral inoculum sometimes passed through the otic epithelium and was inadvertently deposited deep within the surrounding mesenchyme, it is uncertain whether all of the labeled ganglion cells and fibrocartilagenous cells in these experiments were actually resident within the otic epithelium at the time they were infected.

\section{Morphology of labeled sensory cells}

HCs and SCs were labeled in both CHAPOL- and RDlacinfected ears. SCs were elongated, spanned the entire epithelial width, and contained a nucleus that was usually small, ovoid, and located beneath the apical HC layer. When heavily labeled with AP reaction product, leaching from the SCs into surrounding tissues was frequently encountered (Fig. $1 K$ ). Commonly, a streak of reaction product could be followed for tens of micrometers from the apical tip of an AP-positive cluster into the acellular tectorial membrane (Fig. $1 K$, arrow). Because the processes of labeled SCs were so densely and diffusely stained within the HC layer, it was often difficult to determine whether or not an adjacent $\mathrm{HC}$ was also labeled. These artifacts of the AP histochemistry made an analysis of clonal composition difficult. By comparison, SCs heavily labeled with $\beta$-galactosidase reaction product displayed no leaching at the apical surface (Fig. $1 L, M, O, P$ ), and less leaching within the epithelium.

Two major types of SCs were noted based on their morphology. In most cases, a single SC nucleus was clearly associated with a single apical and a single basal process. The most common type 


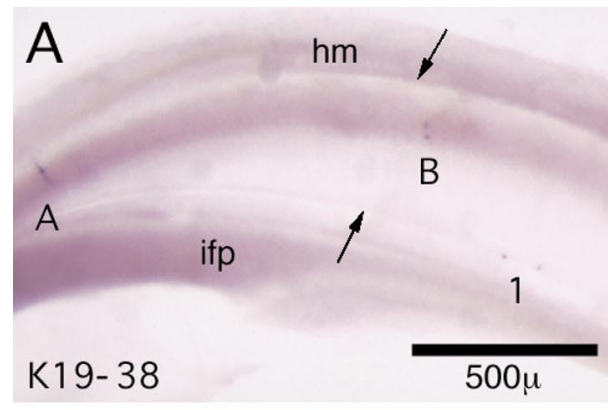

D
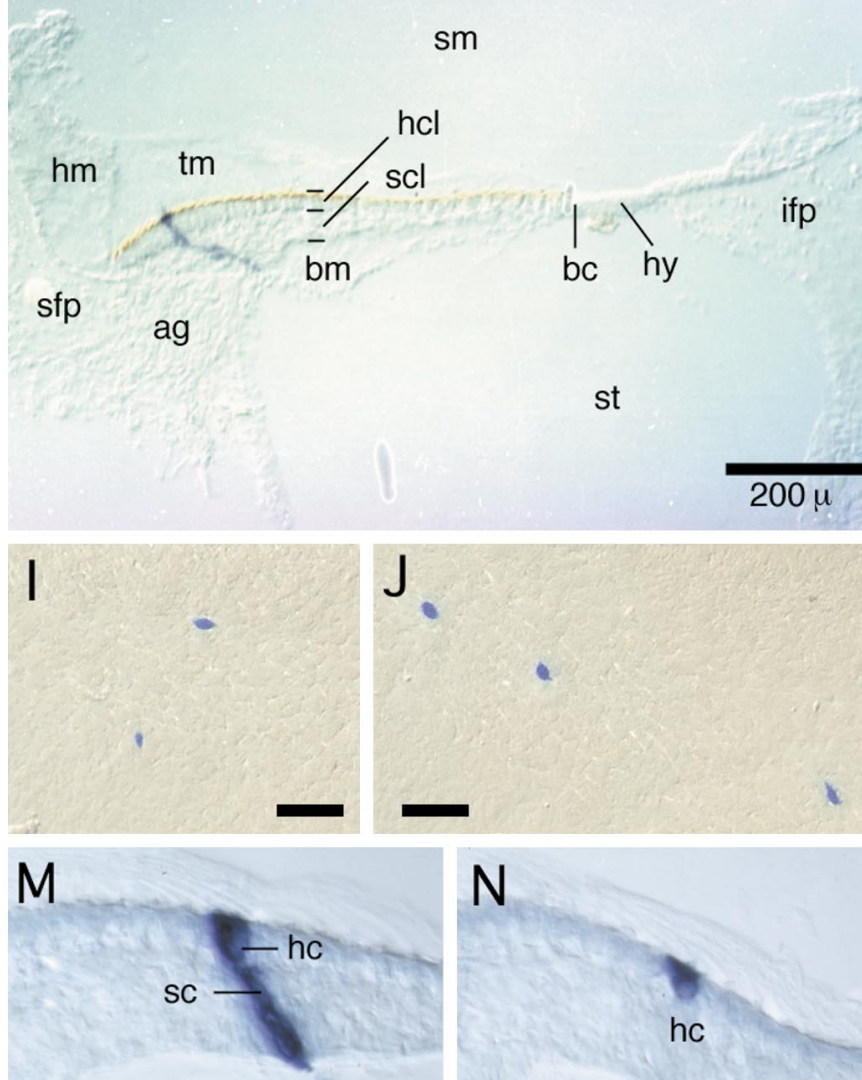

K9- $10 \mathrm{cl}$ one C

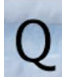

Q

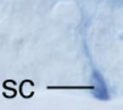

K9- 7 clone B st

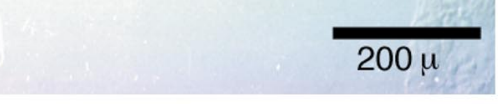

\&.
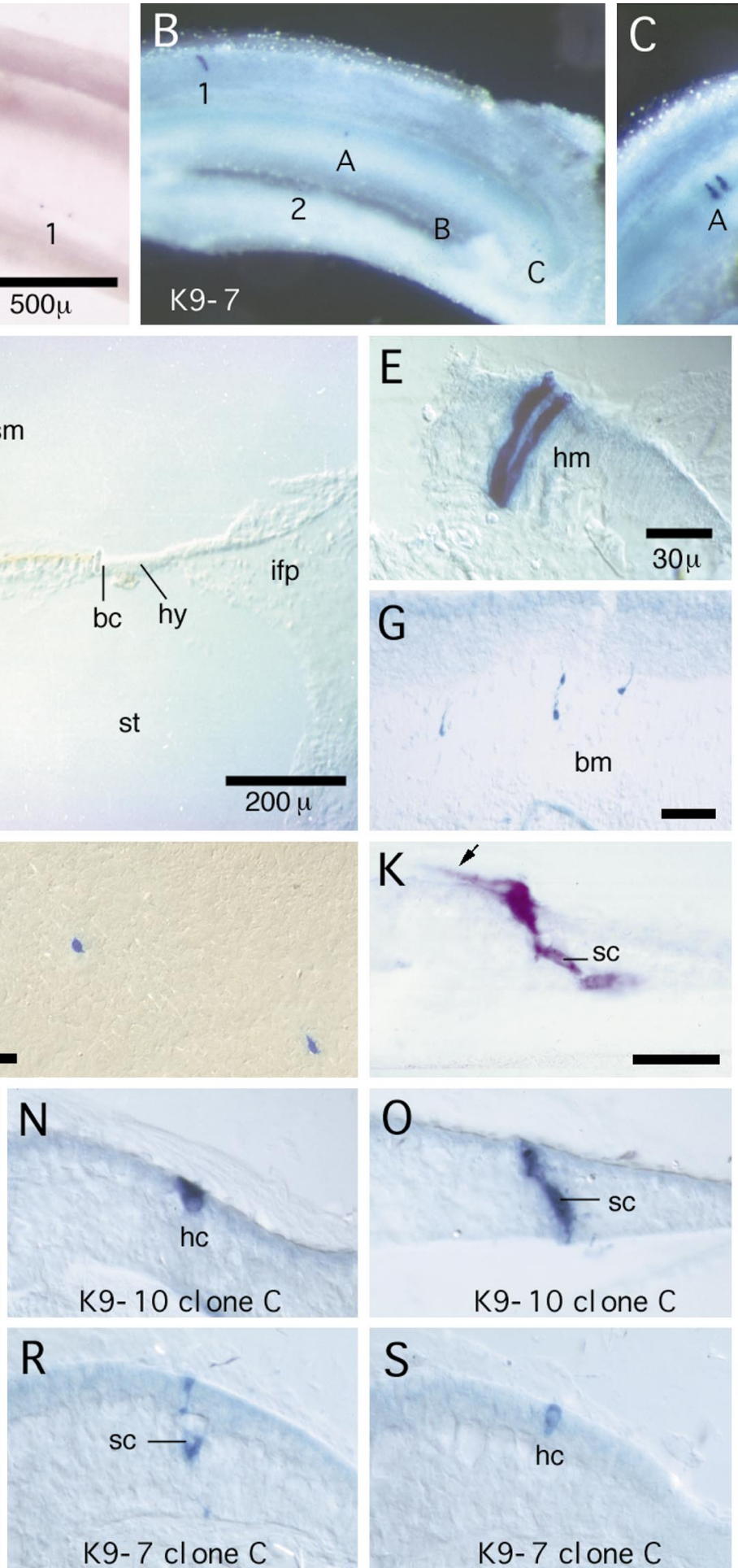

K9- 10 cl one C

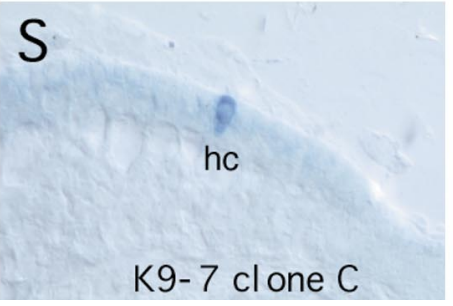

K9- 10
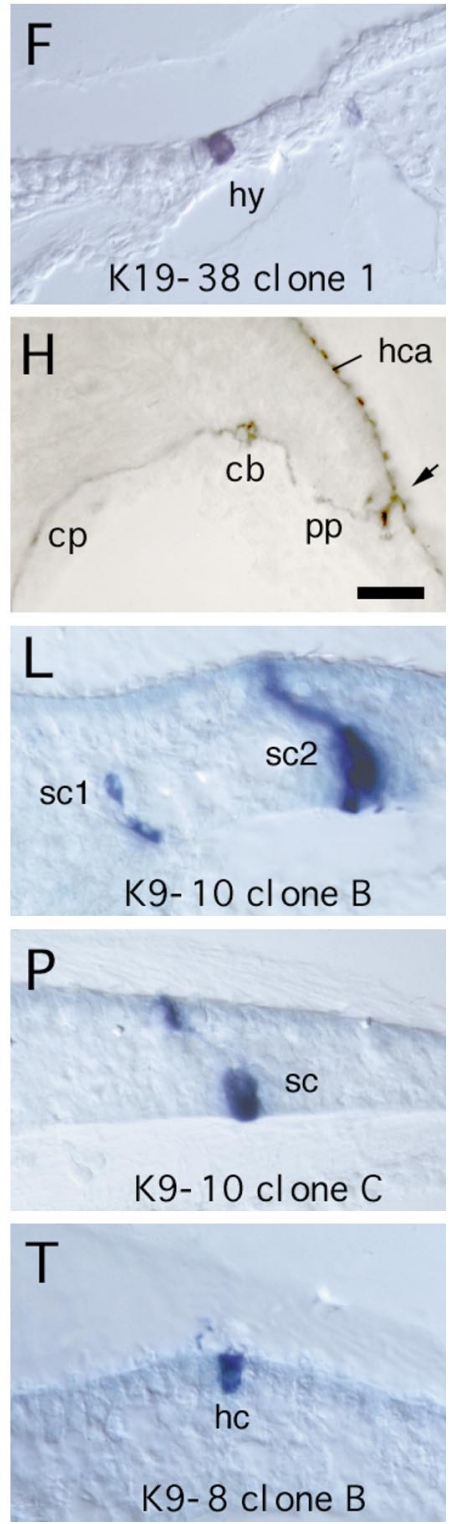

Figure 1. Sensory and nonsensory clones of the inner ear. $A, D, F, H$, and $K$ are from CHAPOL-infected ears that were processed for AP histochemistry. All other panels are from RDlac-infected ears and were processed for $\beta$-galactosidase histochemistry. Specimen number is shown at the bottom of the panels. Sensory clones are indicated by letters and nonsensory clones by numbers. Surface views are shown for $A-C$; the superior (neural) edge is up and proximal is to the left. Scale bar in $A$ applies to $A-C$. Sections are shown for $D-T$. Orientation for $D-T$ (except $G-J$ ) is indicated in $D$, with the superior (neural) edge to the left and the apical surface of the BP up. Scale bar in $E$ shows the scale for $E, F$ and $L-T$. Scale bars: $G-K, 30 \mu \mathrm{m}$. Abbreviations for all panels are: $a g$, auditory ganglion; $b c$, border cells; $b m$, basilar membrane; $h y$, hyaline cells; $h m$, homogene cells; $h c$, hair cell; $h c a$, hair cell antigen; $h c l$, hair cell layer; if $p$, inferior fibrocartilagenous plate; $s c$, supporting cell; scl, supporting cell layer; sfp, superior fibrocartilagenous plate; $s m$, scala media; $s t$, scala tympani; $t m$, tectorial membrane. All panels except $I$ and $J$ show ears processed at E17-E18. $A$, Clone 1 is in the hyaline cell area and can also be seen in F. Arrows point to the superior and inferior edges of the sensory part of the BP. B, Clone 1 is in the homogene cell area. Clone 2 is in the hyaline cell area. Clone $B$ is too small to detect at this magnification. This ear is smaller than normal because the embryo was developmentally delayed by two stages, based on measurements of the third toe. $C$, Clones 1 and 2 are in the homogene cell area. Clones $B$ and $E$ both contain SCs of the delicate phenotype (see Results) that were located above the habenula perforata. D, Low-power orientation. Figure legend continues. 
had relatively thick processes that often expanded at the apical and basal surfaces (Fig. 1L, cell 2). These SCs were nearly always tilted in the neural-abneural dimension, with an apical end that was more neural than the basal end. This orientation explains why these cells so often appeared as tangential streaks when viewed from the apical surface in whole mounts. A second type of SC was observed that was more delicate in appearance. Because this cell type was visible in whole mounts (Fig. $1 C$, clone $E$ and part of clone $B$ ) as well as in sections (Fig. $1 L$, cell $s c 1$; Fig. $1 Q, R$ ), it is unlikely to be an artifact of sectioning. In some of these delicate cells, the nucleus was located on the basal side of the epithelium, immediately adjacent to the basal lamina (Fig. $1 Q$ ). This nuclear position was unusual among the thick SC types. The delicate SCs are most obvious, and easier to quantify, when they are spatially separated from the thicker SCs. Spatially isolated cells of the delicate phenotype represent only $\sim 4 \%$ of the SCs in the $\beta$-galactosidase-labeled data set.

$\mathrm{HC}$ nuclei were recognized as being larger, round, and located as a single apical row. By definition, the somata of HCs were always confined to the apical part of the epithelium. Labeled HCs were more easily identified in RDlac-infected ears, because their nuclear outline was often quite obvious, and their cell bodies were evenly filled with $\beta$-galactosidase reaction product. In many instances, the apical bundle of the labeled HC was evident using Nomarski optics, although the bundles typically did not label well with $\beta$-galactosidase. Short (Fig. $1 M, N$ ) and tall (Fig. 1T) HC morphologies were evident, as well as one HC with less mature morphology (Fig. 1S).

\section{Definition of a sensory clone}

Examination of labeled cells in whole-mount preparations did not reveal any obvious spatial relationship between the sensory and nonsensory clusters within an ear. Furthermore, each could occur independently of the other in that some ears had only sensory and others only nonsensory cluster(s). Therefore, we made the assumption that the two types of clusters were not clonally related, with only two exceptions (Fig. 2, clone K17-1B). The recognition of a clone is based on 45 specimens that had only a single sensory cluster and, thus, could be unambiguously identified as individual clones. These clones usually consisted of one or more intensely labeled cells that were closely spaced. In some instances, the individual cells of the clone were separated from one another by a few unlabeled cells, usually not exceeding the width of one to three HCs $(20-30 \mu \mathrm{m})$. Operationally, labeled cells separated by at least $60 \mu \mathrm{m}$ were considered separate clones. The sensory clusters were widely separated and relatively easy to distinguish in all but three of the CHAPOL-infected ears (which are not included in the analysis) and several of the RDlac-infected ears. One such RDlac-infected specimen for which clonal assignments were difficult is shown in Figure $1 C$; this ear was nonetheless included in the analysis because cell types were so easy to score in this case. These (and other) specimens may thus contain either "lumping errors" in which unrelated cells are considered a clone, or "splitting errors", in which related cells are considered to be in separate clones. Using the above criterion, we counted an average of $0.96 \pm 1.26(\mathrm{SD})$ sensory clones per ear in CHAPOL-injected specimens and $1.7 \pm 2.38(\mathrm{SD})$ in RDlac-injected ears. There were a total of 104 sensory clones from 52 CHAPOL-infected specimens, and 91 sensory clones from 31 RDlac-infected specimens. RDlac infection was preferred for the analysis of sensory cell composition, because there was less ambiguity in cell-type identification with $\beta$-galactosidase as compared AP histochemistry (see Materials and Methods). On the other hand, CHAPOLinfected specimens were especially valuable because of their better statistical analysis (see Results below). The morphological criterion of a clone from whole-mount observation of CHAPOLinfected ears could then be applied to the RDlac data set with more confidence. CHAPOL had the added advantage of allowing for the verification of clonal assignment in a small number of cases because this virus stock contained a variable DNA tag, as described later.

\section{Cellular composition of sensory clones}

A key goal of the present study was to determine whether HCs and SCs were clonally related. For this analysis, it was critical to be able to count and type every cell in a clone. Cell types were sometimes evident from examination of whole-mount specimens of $\beta$-galactosidase-expressing clones, particularly if the cells were slightly dispersed. In tightly clustered clones, this method was insufficient to count cells. In all cases, cell-type identification was confirmed by examination of sectioned material.

Cellular composition could be clearly determined for 41 clones distributed across $17 \beta$-galacosidase-stained ears. Whole-mount drawings were generated for 15 of these ears and are shown in Figure 2; the other two ears were sectioned in toto on E11. A summary of all 41 clones is shown in Figure 3.

Because the viral genome will only integrate into one of the two daughter cells of an infected progenitor, only one-half of the lineage is expected to be visible from a given infected cell. If the daughter cell inheriting the virus becomes postmitotic, then a single cell clone would result. Approximately $40 \%$ of the clones $(n=16)$ were composed of a single cell that was either an $\mathrm{HC}$ or an SC. Because there were fewer ambiguities in identifying single cells (and in particular single HCs), single-cell clones were less likely to be eliminated from the data set and are therefore somewhat over-represented. The 16 one-cell clones were approximately equally distributed between the two cell types.

Among the remaining 25 clones, there were six that consisted of only SCs and one that included SCs, border cells, and hyaline cells. None of the multi-cell clones consisted of only HCs. There were 18 examples of clones containing both HCs and SCs, suggesting that the two cell types can arise from a common progen-

\section{$\leftarrow$}

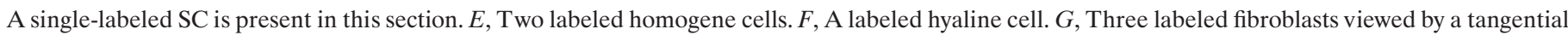

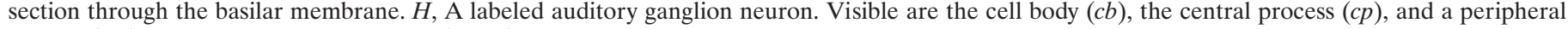

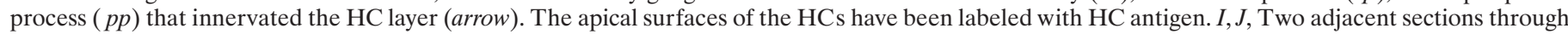

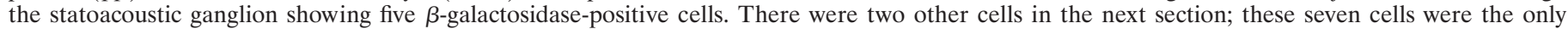

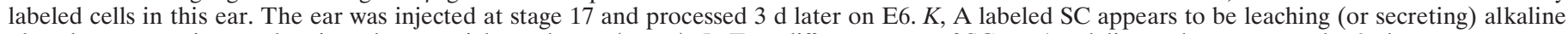

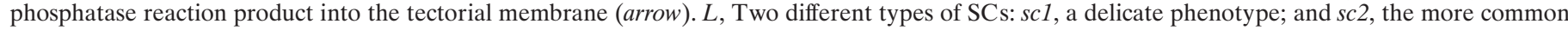

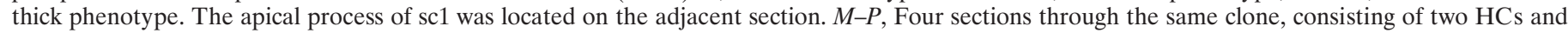

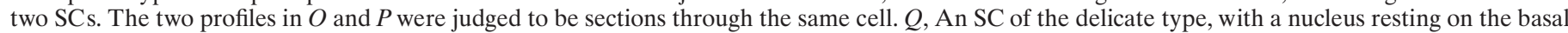

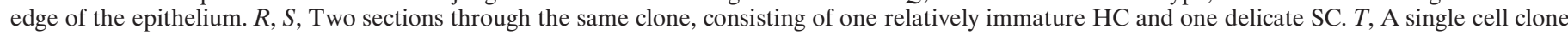
consisting of one $\mathrm{HC}$. 


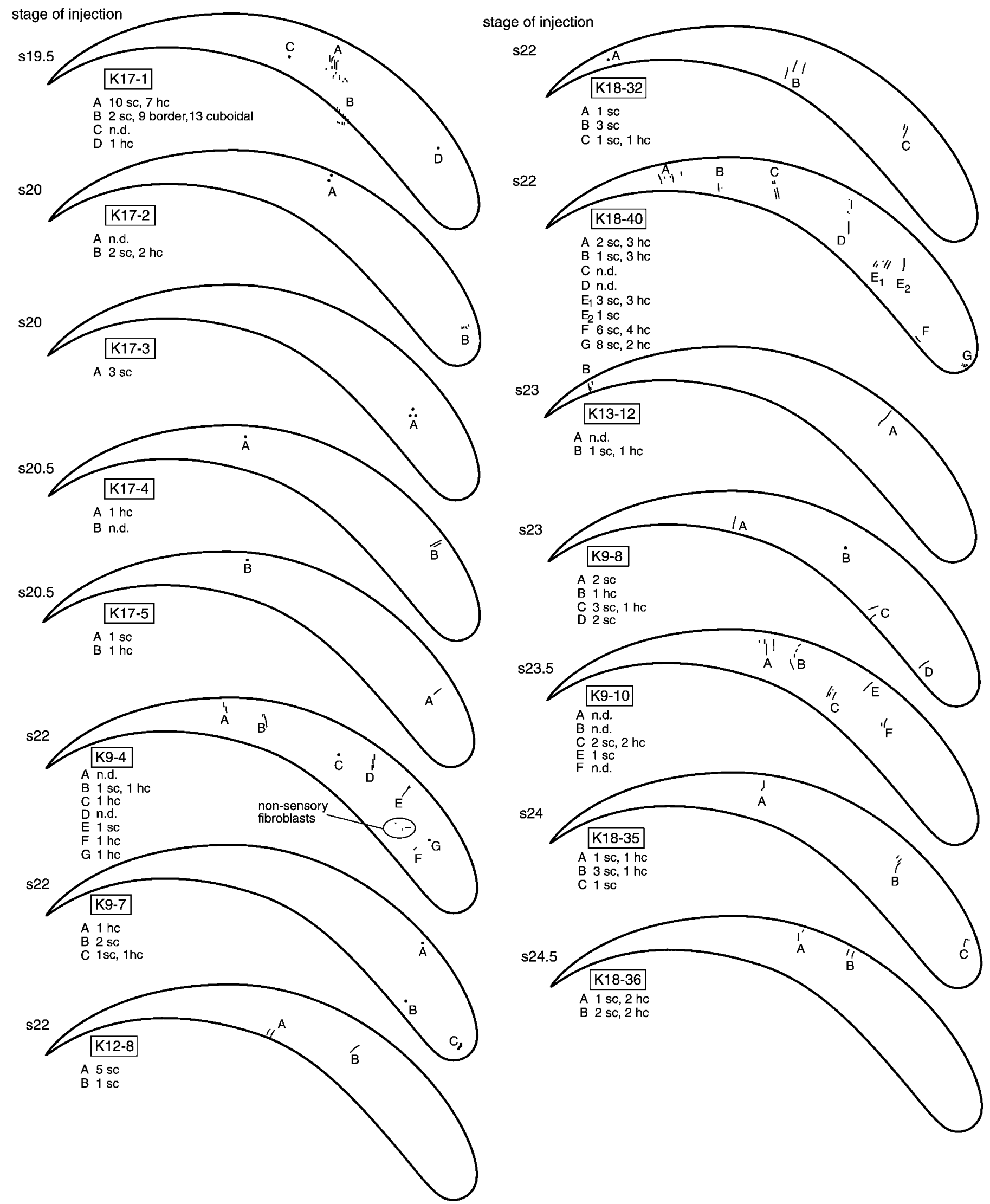

Figure 2. Drawings of RDlac-infected clones on the BP. The 15 ears from which clonal composition was analyzed are presented as they appeared in whole mounts viewed with a dissection microscope. Only the sensory clones are mapped (except as noted) and indicated by capital letters. n.d., Not determined; these are clones for which clonal composition could not be determined with confidence. 


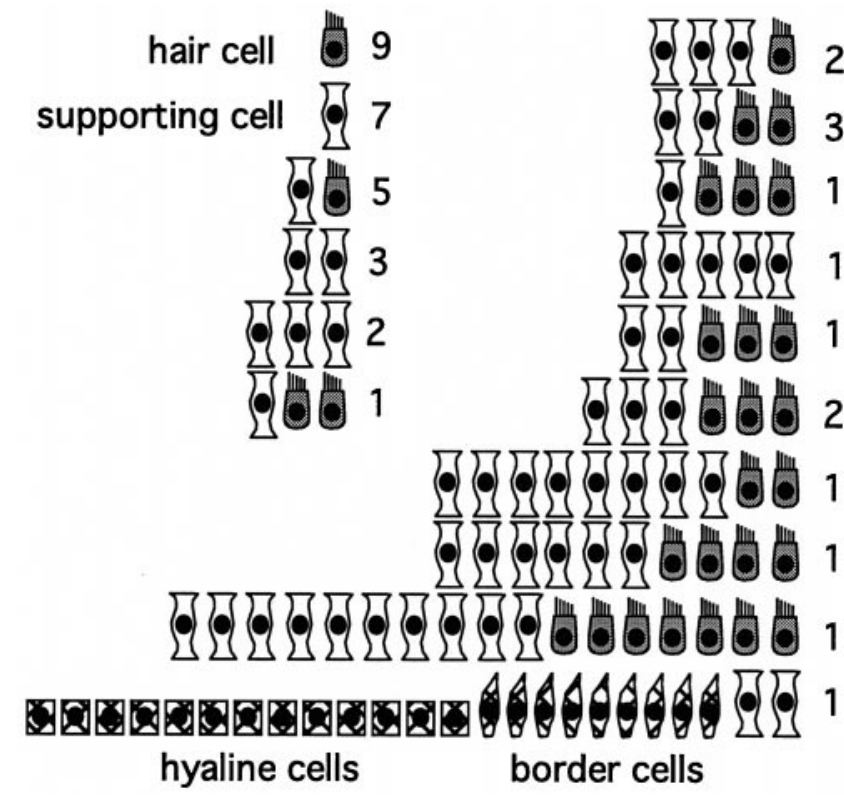

Figure 3. Cellular composition of sensory clones. Numbers to the right of each diagram refer to the number of observations of a clone with the indicated cellular composition.

itor. The example shown in Figure $1, M-P$, is a four-cell clone comprised of two SCs and two HCs. In this case, the profiles shown in Figure 1, $O$ and $P$, were judged to be derived from a single SC that had been cut in half during sectioning.

The two-cell clones were of particular interest in establishing whether a progenitor cell can remain bipotential up to its final mitotic division. The two-cell clones were composed of either two SCs $(n=3)$ or one HC and one SC $(n=5)$. An example of the latter can be seen in Figure 1, $R$ and $S$.

Overall, the ratio of SCs to HCs among the 126 identified sensory cells was 1.6:1. Because of greater ambiguity among clones containing many SCs, leading to their elimination from quantitative assessment, we expect that this ratio may be artificially skewed toward HCs. Extensive cell counts by Goodyear and Richardson (1997) have shown that the ratio of the two cell types varies with position, being $1.7: 1$ in the central-distal portion, 2.1:1 in the superior-proximal edge, and 2.9:1 in the inferiorproximal edge (Goodyear and Richardson, 1997) on E12. Our sample size was too small to ask whether our data show a similar trend.

There were three clones in which the number of HCs exceeded the number of SCs: a three-cell clone consisting of two HCs and one SC, a four-cell clone consisting of three $\mathrm{HCs}$ and one $\mathrm{SC}$, and a five-cell clone consisting of three HCs and two SCs (Fig. 3). It is not possible from these examples to ascertain whether a single mitotic division can give rise to two HCs: asymmetrical divisions that yield one $\mathrm{HC}$ and one mitotic progenitor cell until a final division into one $\mathrm{HC}$ and one $\mathrm{SC}$ could also generate these ratios of cell types.

\section{Clone size versus position}

Clones used for cellular composition were mapped onto one BP to ask whether clone size was related to position (Fig. 4). There was a tendency for the smallest clones to map to the superior (neural) half of the epithelium; $>80 \%$ of the one-cell clones were located in this half. In contrast, three of the four largest clones

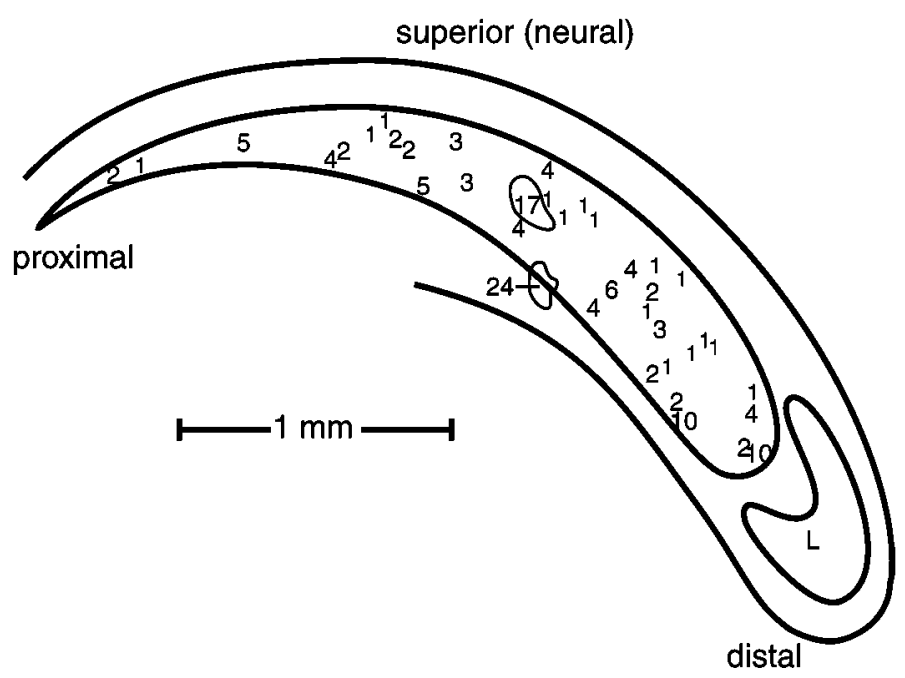

Figure 4. Clone size verses position on the BP. Numbers represent the number of cells in 39 of the 41 sensory clones represented in Figure 3. L, Lagena.

were located at the extreme inferior (abneural) or distal edge of the epithelium. These distributions are consistent with the reported superior-proximal-to-inferior-distal gradient in final mitotic divisions in the BP (Katayama and Corwin, 1989). Only one large clone (K17-1A) was centrally located.

\section{Dispersed versus clustered clones}

Some reorganization of the cells in the distal BP is expected between E7 and E15, based on the pattern of thymidine labeling (Katayama and Corwin, 1993). In addition, there are local cellcell rearrangements between E9 and E12 that result in each $\mathrm{HC}$ being contacted by a larger number of SCs, as well as each SC contacting more HCs (Goodyear and Richardson, 1997). It might therefore be expected that sister cells could become separated by mixing that occurs after their mitotic division. Indeed, we did see evidence that sister cells were separated from one another by one to several cell diameters. Clones containing cells that were separated by larger distances would have been missed because of the criterion used to designate a clone. The more conservative criterion was used to minimize potential lumping errors.

\section{Statistical analysis of clonality}

If our definition of a sensory clone is correct, and lumping or splitting errors are relatively infrequent, then a distribution of the number of clones per ear across the data set should approximate a Poisson distribution (Ryder and Cepko, 1994). The pools of ears infected with different virus stocks must be independently subjected to statistical analysis to estimate the accuracy of clonal assignments. Ideally, this analysis should be done on embryos that all received injections at the same stage. This would minimize variation caused by the amount of virus that was injected into each ear (typically more for larger otocysts), or other systematic variations in the number of clones per ear as a function of the stage of injection (such as proportion of cells undergoing mitosis). On the other hand, the statistical power is increased by including a large number of specimens.

As a compromise to minimize variability caused by stage of injection, but to maximize the sample size, we sampled the middle range of injection stages, pooling embryos from stages 21-26 $($ mean $=$ stage 24$)$ for the CHAPOL-infected ears. These represented 80 ears or $76 \%$ of the CHAPOL data set. The results 


\begin{tabular}{lcc}
\hline \multicolumn{3}{l}{$\begin{array}{l}\text { Table 1. Statistical analysis of clonality assuming a Poisson } \\
\text { distribution for } 80 \text { ears injected with CHAPOL at stages }\end{array}$} \\
\multicolumn{2}{l}{ 21-26 } \\
Sensory clones per ear & Observed (O) & Expected (E) \\
\hline 0 & 35 & 32.9 \\
1 & 29 & 29.2 \\
2 & 9 & 13.0 \\
$\geq 3$ & 7 & 4.9
\end{tabular}

This analysis tested the hypothesis that the presumed clones did result from single infection events following the Poisson distribution as described by Ryder and Cepko (1994). These data are consistent with the hypothesis with $0.50>p>0.25$ for $2 \mathrm{df}$ using the $\chi^{2}$ test for goodness of fit. $\mu=$ total number of infection events per total number of embryos $(71 / 80=0.888) . P(x)=$ probability of $x$ infection events occurring in one embryo $=\exp (-\mu) \mu^{\mathrm{x}} / \mathrm{x}$ !. $F(x)=$ frequency of $x$ infection events occurring in one embryo in a data set of 80 embryos. $\mathrm{E}=$ expected value of $F(x)=$ $P(x)^{*} 80 . \mathrm{O}=$ observed value of $F(x)$.

$$
\chi^{2}=\sum \frac{(\mathrm{O}-\mathrm{E})^{2}}{\mathrm{E}}=2.285
$$

Note: Because the parameter used to derive $\mu$ was based on the sample data itself, it is necessary to subtract an additional degree of freedom from the number of categories $(k=4)$, leaving $2 \mathrm{df}$.

\begin{tabular}{lcc}
\hline $\begin{array}{l}\text { Table 2. Statistical analysis of clonality assuming a Poisson } \\
\text { distribution for } \mathbf{5 5} \text { ears injected with RDlac at stages } \mathbf{1 8 - 2 8}\end{array}$ \\
\begin{tabular}{lll} 
Sensory clones per ear & Observed (O) & Expected (E) \\
\hline 0 & 24 & 10.5 \\
1 & 11 & 17.4 \\
2 & 10 & 14.4 \\
$\geq 3$ & 10 & 12.7
\end{tabular}
\end{tabular}

This analysis tested the hypothesis that the presumed clones did result from single infection events following the Poisson distribution (see Table 1 for statistical procedure). These data are inconsistent with the hypothesis for $2 \mathrm{df}$ using the $\chi^{2}$ test for goodness of fit $\left(\chi^{2}=21.6,0.001>p\right)$; therefore we must reject the hypothesis.

indicated that the distribution in the number of clones per ear did approximate a Poisson distribution (Table 1). There was a slight tendency for the number of ears with greater than three clones to be more frequent than expected, perhaps suggesting that some splitting errors may be present when a single clone has been scored as two clones.

In contrast to the CHAPOL data set, the 55 RDlac-infected ears did not conform well to a Poisson distribution when subjected to statistical analysis (Table 2). This was true even if the analysis was restricted to the subset of 32 ears that were injected at stages 21-26 (data not shown). It should be noted that there was additional variability among the RDlac data set in the composition of the fixative used as well as the length of time in fixative. Two small batches that had the longest delays between fixation and $\beta$-galactosidase staining (up to $12 \mathrm{~d}$ ) gave no clones in the BP ( $n=6$ ears), whereas two batches that had a $1 \mathrm{~d}$ delay gave a larger than average number of sensory clones per ear (mean $=2.4, n=11$ ears). The fact that all specimens were not treated the same could have compromised the statistical analysis in the overall data set. Nonetheless, among the 17 RDlac-infected ears that were used in the clonal composition analysis, there was an average of only 3.3 sensory clusters per ear (range $=$ one to eight clusters per ear). This relatively small number of clusters per ear raises confidence that individual clones can be identified with reasonable accuracy, despite the poor statistical outcome for the entire data set.

\section{Summary of labeled cells analyzed by PCR and sequencing}

As an independent verification of clonal assignments, we attempted to identify the viral genome that was resident in different cells in the same clone or in other clones from the same ear. This procedure was only rarely successful for individual sensory clones, because the combined PCR amplification-sequencing procedure had a relatively low rate of recovery $(35 \%)$ and because sensory clone size was so small. Results are shown in Table 3 for those cases in which at least two independent picks from the same ear were sucessfully amplified and sequenced to determine the viral genome(s) present. There was only a single case in which more than one pick through the same sensory cluster generated unambiguous sequence information. In this slightly dispersed cluster (19S-1, clone A), two different sequences were obtained from SCs separated from one another by one negative section $(\sim 20 \mu \mathrm{m})$. Therefore, we conclude that a lumping error occurred, in which two different clones were scored as one. Approximately $300 \mu \mathrm{m}$ away in this same ear, separate picks from a HC (19S-1, clone B) and a homogene cell from the same section did not share the same sequence with one another or with clone A and were therefore verified as being members of different clones. In another case (18S-35), the SCs of sensory clone B were confirmed to be unrelated to ganglion cells picked from the same section. Although the data are quite limited, they appear to confirm our initial assumption that sensory and nonsensory clones are usually unrelated.

Multiple picks from nonsensory cells were more often successful in generating sequence information, presumably because such clones tended to be larger and, in some cases, more dispersed. Ear $18 \mathrm{~S}-35$ contained cells in the auditory ganglion that spanned three sections $(80 \mu \mathrm{m})$ and yet shared the same sequence. Another ganglion cell located $0.5 \mathrm{~mm}$ away was unrelated to the first cluster. Ear 17S-52 had three independent picks, two from the auditory ganglion and one from the basilar membrane, that were found to contain the same sequence, although they spanned a total of nine sections $(180 \mu \mathrm{m})$. These labeled cells could therefore be judged to be clonally related.

Sequence information was also obtained from two picks that were judged to be AP-negative: in each case the sequence obtained was unique, and distinct from sequence obtained from AP-positive picks from the same ears. The AP-negative samples that generated the $121 \mathrm{bp}$ product were presumed to contain virus that was either transcriptionally silent or that was making undetectable levels of AP protein. A high rate of PCR-based detection of virus in AP-negative samples has been reported previously using the same viral stock in the chicken diencephalon (Golden and Cepko, 1996). In that study, it was determined that the viral sequences amplified from AP-negative picks were usually different from those amplified from AP-positive picks for all but 5\% of the clones. In addition, larger picks were more often associated with silent viral sequences than smaller picks. Because our negative picks were nearly always from larger samples than the positive picks, we probably increased the likelihood of finding silent genomes in the negative samples.

\section{DISCUSSION}

\section{HCs and SCs share a common progenitor}

Retrovirus-based lineage analysis was used to show that single clones in the developing chicken BP can contain both HCs and SCs. Two-cell clones were observed that consisted of one of each 


\begin{tabular}{|c|c|c|c|c|c|}
\hline Ear & Pick & $\begin{array}{l}\text { Clone } \\
\text { type }\end{array}$ & AP & PCR & $\begin{array}{l}\text { Sequence } \\
\text { ID number }\end{array}$ \\
\hline $17 \mathrm{~S}-38$ & Section 116 Ganglion & $\mathrm{g}$ & $(+)$ & $(+)$ & 18 \\
\hline 17S-38 & Section 119 Ganglion & $\mathrm{g}$ & $(+)$ & $(+)$ & 16 \\
\hline $17 \mathrm{~S}-38$ & Section 121 Ganglion & $\mathrm{g}$ & $(+)$ & $(+)$ & 17 \\
\hline $17 \mathrm{~S}-52$ & Section 25 B.m. fibroblasts & $\mathrm{f}$ & $(+)$ & $(+)$ & 09 \\
\hline $17 \mathrm{~S}-52$ & Section 31 Ganglion & $\mathrm{g}$ & $(+)$ & $(+)$ & 09 \\
\hline $17 \mathrm{~S}-52$ & Section 35 Ganglion & $\mathrm{g}$ & $(+)$ & $(+)$ & 09 \\
\hline $18 \mathrm{~S}-2$ & Section 97 B.m. fibroblasts & $\mathrm{f}$ & $(+)$ & $(+)$ & 08 \\
\hline $18 \mathrm{~S}-2$ & Section 101 Inferior cartilage & $\mathrm{f}$ & $(+)$ & $(+)$ & 08 \\
\hline $18 \mathrm{~S}-2$ & Section 101 AP-negative & $\mathrm{x}$ & $(-)$ & $(+)$ & 03 \\
\hline $18 \mathrm{~S}-35$ & Section 22 Ganglion & g & $(+)$ & $(+)$ & 20 \\
\hline $18 \mathrm{~S}-35$ & Section 23 Ganglion & $\mathrm{g}$ & $(+)$ & $(+)$ & 20 \\
\hline $18 \mathrm{~S}-35$ & Section 24 Ganglion & $\mathrm{g}$ & $(+)$ & $(+)$ & 20 \\
\hline $18 \mathrm{~S}-35$ & Section 49 Ganglion & g & $(+)$ & $(+)$ & 19 \\
\hline $18 \mathrm{~S}-35$ & Section 49 Clone B-SCs & $\mathrm{s}$ & $(+)$ & $(+)$ & 21 \\
\hline 19S-1 & Section 40 Clone A-SCs \& HC tip & $\mathrm{s}$ & $(+)$ & $(+)$ & 04 \\
\hline 19S-1 & Section 42 Clone A-SCs & s & $(+)$ & $(+)$ & 14 \\
\hline 19S-1 & Section 57 Clone B-HC & $\mathrm{s}$ & $(+)$ & $(+)$ & 01 \\
\hline 19S-1 & Section 57 Homogene cell & $\mathrm{n}$ & $(+)$ & $(+)$ & 06 \\
\hline $20 \mathrm{~S}-48$ & Section 4 AP-negative & $\mathrm{x}$ & $(-)$ & $(+)$ & 15 \\
\hline $20 \mathrm{~S}-48$ & Section 5 Clone A-SCs & $\mathrm{s}$ & $(+)$ & $(+)$ & 07 \\
\hline 21S-14 & Section 6 Nonsensory & $\mathrm{n}$ & $(+)$ & $(+)$ & 05 \\
\hline 21S-14 & Section 25 Clone $\mathrm{C}$ & $\mathrm{s}$ & $(+)$ & $(+)$ & 11 \\
\hline
\end{tabular}

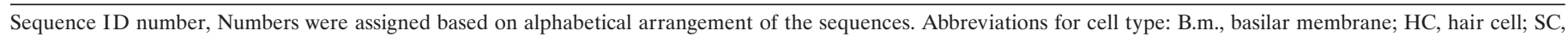
supporting cell. Abbreviations for clone type: f, fibroblast; g, ganglion; n, non-sensory epithelial; s, sensory; x, AP-negative picks.

cell type. This further suggests that progenitor cells giving rise to this lineage remain bipotential up to their final mitotic division. Thus, like the retina (Turner and Cepko, 1987; Holt et al., 1988; Wetts and Fraser, 1988; Turner et al., 1990; Fekete et al., 1994), the inner ear sensory epithelium can generate both sensory receptor cells and "non-neural" SCs from a common progenitor. The olfactory sensory epithelium appears to be different, in that perhaps three different lineages coexist: a horizontal basal cell lineage, a globose cell-olfactory neuron lineage, and a sustentacular cell lineage (that was not infected with retrovirus) (Caggiano et al., 1994).

The interpretation of two-cell clones as representing the outcome of a final mitotic division rests on the assumption that cell death is not a widespread phenomenon in this organ. Our own data suggest that cell death is present, although not overly abundant, in or near the BP from E6 to E8 (Fekete et al., 1997). A small but significant amount of programmed cell death is present during the initial stages of HC differentiation in the rat vestibular organs, but subsequently disappears (Zheng and Gao, 1997).

One possible source of error in this study is the existence of clonal assignment errors. In the only case in which the insert tag could be amplified and sequenced from more than one cell in a sensory clone, we concluded that a lumping error had occurred, whereby two unrelated cells were grouped together as a clone. Alternatively, there could have been other unrelated but infected cells in these picks that were not detectable by AP histochemistry, but could be the source of the alternative sequences. Negative picks did amplify in $24 \%$ of the cases, suggesting that this was not a rare event.

On the other hand, a statistical test of fit to a Poisson distribution found a slight over-representation of ears containing mul- tiple clones compared with the prediction for the CHAPOLinfected ears. Thus, there may be cases in which clonally related cells were erroneously "split" into two (or more) clones. Unfortunately, we were unable to use PCR sequencing of viral tags to assess the extent of such splitting errors because of our limited data set.

\section{Clonal analysis and cell fate determination}

The goal now will be to discover the intrinsic and/or extrinsic signals that direct cell fate specification in sensory organs of the inner ear such that HCs and SCs are generated in the correct proportions and with the appropriate cell-cell contacts. It has been proposed that the specification of $\mathrm{HC}$ and SC fates might be mediated through lateral inhibition (Cotanche, 1987; Corwin et al., 1991; Lewis, 1991). Although the argument was originally based on the morphological arrangement of the two cell types and the synchrony of their generation, further evidence that hair cell-bearing sensory organs express members of the Notch/Delta lateral-inhibitory signaling pathway is accumulating (Whitfield et al., 1997). Lateral inhibition is based on the premise that two alternating cell types arise from a homogenous pool of cells, called an equivalence group. A de facto requirement of this model is that no intrinsic bias in cell fates will exist among the progenitor cells giving rise to the equivalence group. That is, a situation in which $\mathrm{HCs}$ and SCs arise from separate progenitors would necessarily rule out a lateral specification model of cell fate choices. The data presented here failed to find evidence for separate pools and are thus consistent with a lateral inhibitory model of cell fate specification. Other models, such as those invoking asymmetric inheritance of a cellular determinant in a stochastic manner, with or without a potential interaction with the 
Notch signaling pathway (Guo et al., 1996), are equally consistent with the lineage analysis presented here.

\section{Variation in the time to viral integration can influence expected clone size}

In considering the range in clone sizes that might be expected from E4 lineages, one must first consider any inherent delays that might occur between the time of injection and the marking of individual progenitor cells by viral integration. This delay has been estimated to take $15 \mathrm{hr}$ on average in E3 chick retina (Fekete et al., 1994), although the range may vary from $9 \mathrm{hr}$ based on protein expression (Homburger and Fekete, 1996) to several days based on in vitro data (Hughes et al., 1981). If the ear is comparable to the retina then, on average, the lineage data presented here may reflect clones derived from progenitors labeled early on the fifth day of incubation (115-130 hr of incubation, or $\sim 120 \mathrm{hr}$ ).

How well is the estimate of $120 \mathrm{hr}$ as the time of integration supported by the data on single cell clones? HCs first become postmitotic at $120 \mathrm{hr}$ of incubation on E5, with roughly onequarter of the sensory epithelium coming out of division in the next $24 \mathrm{hr}$ (Katayama and Corwin, 1989). Single-cell clones were observed in $39 \%$ (16 of 41) of the clones analyzed for cell composition. Among the clones containing HCs, 33\% (9 of 27) were single-cell clones. These data suggest that the time of viral integration was close to the time of final mitotic division for a moderate proportion of progenitor cells, whereas the majority $(60-70 \%)$ were labeled before the final mitotic division.

At the high end of the range, the maximal clone sizes expected can be calculated from the length of the cell cycle and the time between virus integration and the cessation of mitosis. Although precise measurements are lacking, the cell cycle seems to lengthen during the first several days of otic vesicle formation. It has been estimated to be $8.5 \mathrm{hr}$ on E1.5 based on population doubling time (Meier, 1978). Cell numbers increase exponentially by fivefold on E3 and again on E4 (Alvarez et al., 1989), suggesting a $10 \mathrm{hr}$ cell cycle. However, such estimates based on cell number will be confounded by nonuniform proliferation in the E4 otic vesicle, as measured by mitotic indices (Alvarez et al., 1989) and BrdU-pulse labeling (H. Lang, M. Bever, and D. Fekete, unpublished observations). Estimates are also complicated by cell death in the otic vesicle of the chicken (Alvarez and Navascués, 1990; Fekete et al., 1997; Frago et al., 1998). By E7, the cell cycle has lengthened to $\sim 12 \mathrm{hr}$ in the BP, based on estimates of cell cycle kinetics (Katayama and Corwin, 1993). For the following calculations, $12 \mathrm{hr}$ is used to estimate cell cycle length from E5 onward. In the $75 \mathrm{hr}$ between integration (120 hr of incubation on average) and the end of cell division ( $~ 195 \mathrm{hr}$ of incubation, Katayama and Corwin, 1989), up to six cell cycles are possible. With exponential growth, clones as large as 64 cells are predicted, although we would expect to see only half the number of cells ( $n=32$ cells) because of asymmetric virus integration. The largest clone had 24 cells and was located along the distal-inferior edge that should remain mitotically active the longest. However, small clones were the norm, even near the edge of the BP, suggesting that asymmetrical divisions were common, with one cell becoming postmitotic, whereas the other continues to divide for a limited period of time. Maximum clone sizes that are smaller than expected could also indicate that the approximate cell cycle time $(12 \mathrm{hr})$ might be too short or that delays to integration of the virus that are $>15 \mathrm{hr}$ are routinely encountered.

\section{The origin of HCs during development and regeneration}

The observation of a common progenitor in development lends further credence to the suggestion that a mitotic progenitor can also give rise to both cell types during regeneration. Direct demonstration of a similar lineage relationship in a mature regenerating inner ear is required to verify this likely possibility. It is also important to note the differences between regeneration and development. During development, a wave of final mitosis sweeps across the epithelium as the progenitor pool ceases to divide. Undifferentiated cells must then choose fates, possibly through cell-cell interactions, such that an overall ratio of two or three SCs for each $\mathrm{HC}$ is obtained. In contrast, many of the regeneration paradigms cause selective $\mathrm{HC}$ loss, leaving a population of (presumably) differentiated SCs undamaged. These SCs then revert to a less differentiated state in which they can reenter mitosis. It is then the progeny of each divided cell that must choose a fate. Whether this process recapitulates the developmental process, perhaps by making use of cell-cell interactions and/or inheritance of asymmetric determinants, is unknown, but it is certainly plausible. In extensively damaged ears, in which both HCs and SCs are lost, the hyaline cells can also proliferate and migrate over the damaged sensory epithelium (Girod et al., 1989; Cotanche et al., 1995), although it is uncertain whether they can generate new sensory cells (for discussion, see Warchol and Corwin, 1996). We observed two clones in which such nonsensory cells appeared to be related by lineage to SCs, suggesting that a multipotent progenitor may be present in development at stage 20 or later.

Although a major response to $\mathrm{HC}$ loss in the chicken $\mathrm{BP}$ is the proliferation of mature SCs, transdifferentiation of SCs is also an option. It is also formally possible that a quiescent, undifferentiated progenitor cell lurks in the sensory epithelium, being stimulated to divide only when HCs are depleted. The presence of such a progenitor would not, a priori, exclude mature SCs as a major source of new HCs. Our results suggest that two morphological types of SCs are present in the E19 chicken BP. The delicate SC type has a phenotype consistent with a precursor cell and it is far less common than its robust neighbor. It also bears some resemblance to an immature $\mathrm{HC}$ as described by Stone et al. (1996). Considerably more work will be required to determine whether this cell type is actually an SC, an immature $\mathrm{HC}$, a precursor cell, and/or a cell with proliferative capacity.

\section{REFERENCES}

Adler HJ, Raphael Y (1996) New hair cells arise from supporting cell conversion in the acoustically damaged chick inner ear. Neurosci Lett 205:17-20.

Adler HJ, Komeda M, Raphael Y (1997) Further evidence for supporting cell conversion in the damaged avian basilar papilla. Int J Dev Neurosci 15:375-385.

Alvarez IS, Martín-Partido G, Rodríguez-Gallardo L, González-Ramos C, Navascués J (1989) Cell proliferation during early development of the chick embryo otic anlage: quantitative comparison of migratory and nonmigratory regions of the otic epithelium. J Comp Neurol 290:278-288.

Alvarez IS, Navascués J (1990) Shaping, invagination, and closure of the chick embryo otic vesicle: scanning electron microscope and quantitative study. Anat Rec 228:315-326.

Bartolami S, Goodyear R, Richardson G (1991) Appearance and distribution of the $275 \mathrm{kDa}$ hair-cell antigen during development of the inner ear. J Comp Neurol 314:777-788.

Caggiano M, Kauer JS, Hunter DD (1994) Globose basal cells are neuronal progenitors in the olfactory epithelium: a lineage analysis using a replication-incompetent retrovirus. Neuron 13:339-352. 
Cepko C (1992) Transduction of genes using retrovirus vectors. In: Current protocols in molecular biology (Ausubel FM, Brent R, Kingston RE, Moore DD, Seidman JG, Smith JA, Struhl K, eds), pp 9.10-9.14. New York: Greene and Wiley-Interscience.

Corwin JT, Cotanche DA (1988) Regeneration of sensory hair cells after acoustic trauma. Science 240:1772-1774.

Corwin JT, Oberholtzer JC (1997) Fish n' chicks: model recipes for hair-cell regeneration? Neuron 19:951-954.

Corwin JT, Jones JE, Katayama A, Kelley MW, Warchol ME (1991) Hair cell regeneration: the identities of progenitor cells, potential triggers and instructive cues. In: Regeneration of vertebrate sensory receptor cells (Bock GR, Whelan J, eds), pp 103-130. Chichester, England: Wiley.

Corwin JT, Warchol ME, Kelley MW (1993) Hair cell development. Curr Opin Neurobiol 3:32-37.

Cotanche DA (1987) Regeneration of hair cell steriociliary bundles in the chick cochlea following severe acoustic trauma. Hear Res 30:181-196.

Cotanche DA, Lee KH (1994) Regeneration of hair cells in the vestibulocochlear system of birds and mammals. Curr Opin Neurobiol 4:509-514.

Cotanche DA, Messana EP, Ofsie MS (1995) Migration of hyaline cells into the chick basilar papilla during severe noise damage. Hear Res 91:148-159.

Dooling RJ, Ryals BM, Manabe K (1997) Recovery of hearing and vocal behavior after hair-cell regeneration. Proc Natl Acad Sci USA 94:14206-14210.

Duckert LG, Rubel EW (1993) Morphological correlates of functional recovery in the chicken inner ear after gentamycin treatment. J Comp Neurol 331:75-96.

Fekete DM (1996) Cell fate specification in the inner ear. Curr Opin Neurobiol 6:533-541.

Fekete DM, Cepko CL (1993) Replication-competent retroviral vectors encoding alkaline phosphatase reveal spatial restriction of viral gene expression/transduction in the chick embryo. Mol Cell Biol 13:2604-2613.

Fekete DM, Perez Miguelsanz J, Ryder EF, Cepko CL (1994) Clonal analysis in the chicken retina reveals tangential dispersion of clonally related cells. Dev Biol 166:666-682.

Fekete DM, Homburger SA, Waring MT, Riedl AE, Garcia LF (1997) Involvement of programmed cell death in morphogenesis of the vertebrate inner ear. Development 124:2451-2461.

Frago LM, León Y, de la Rosa EJ, Gómez-Miñoz A, Varela-Nieto I (1998) Nerve growth factor and ceramides modulate cell death in the early developing inner ear. J Cell Sci 111:549-556.

Girod DA, Duckert LG, Rubel EW (1989) Possible precursors of regenerated hair cells in the avian cochlea following acoustic trauma. Hear Res 42:175-194.

Girod DA, Tucci DL, Rubel EW (1991) Anatomical correlates of functional recovery in the avian inner ear following aminoglycoside ototoxicity. Laryngoscope 101:1139-1149.

Golden JA, Cepko CL (1996) Clones in the chick diencephalon contain multiple cell types and siblings are widely dispersed. Development 122:65-78.

Golden JA, Fields Berry SC, Cepko CL (1995) Construction and characterization of a highly complex retroviral library for lineage analysis. Proc Natl Acad Sci USA 92:5704-5708.

Goodyear R, Richardson G (1997) Pattern formation in the avian auditory system: evidence for cell rearrangement. J Neurosci 17:6289-6301.

Guo M, Jan LY, Jan YN (1996) Control of daughter cell fates during asymmetric division: interaction of numb and notch. Neuron 17:27-41.

Hamburger V, Hamilton HL (1951) A series of normal stages in the development of the chick embryo. J Morphol 88:49-91.

Holt CE, Bertsch TW, Ellis HM, Harris WA (1988) Cellular determination in the Xenopus retina is independent of lineage and birth date. Neuron 1:15-26.

Homburger SA, Fekete DM (1996) High efficiency gene transfer into the embryonic chicken CNS using B-subgroup retroviruses. Dev Dyn 206:112-120.
Hughes SH, Vogt PK, Stubblefield E, Bishop JM, Varmus HE (1981) Integration of avian sarcoma virus DNA in chicken cells. Virology 108:208-221.

Jones JE, Corwin JT (1996) Regeneration of sensory cells after laser ablation in the lateral line system: hair cell lineage and macrophage behavior revealed by time-lapse video microscopy. J Neurosci 16:649-662.

Katayama A, Corwin JT (1989) Cell production in the chicken cochlea. J Comp Neurol 281:129-135.

Katayama A, Corwin JT (1993) Cochlear cytogenesis visualized through pulse labeling of chick embryos in culture. J Comp Neurol $333: 28-40$.

Lewis J (1991) Rules for the production of sensory cells. In: Regeneration of vertebrate sensory receptor cells (Bock GR, Whelan J, eds), pp 25-53. Chichester, England: Wiley.

Li L, Forge A (1997) Morphological evidence for supporting cell to hair cell conversion in the mammalian utricular macula. Int J Dev Neurosci 15:433-446.

Meier S (1978) Development of the embryonic chick otic placode. Anat Rec 191:447-458.

Morgan BA, Fekete DM (1996) Manipulating gene expression with replication competent retroviruses. In: Methods in avian embryology (Bronner-Fraser M, ed), pp 185-218. San Diego: Academic.

Muller M, Smolders JW, Ding-Pfennigdorff D, Klinke R (1997) Discharge properties of pigeon single auditory nerve fibers after recovery from severe acoustic trauma. Int J Dev Neurosci 15:401-416.

Oesterle EC, Rubel EW (1993) Postnatal production of supporting cells in the chick cochlea. Hearing Research 66:213-224.

Oesterle EC, Cunningham DE, Rubel EW (1992) Ultrastructure of hyaline, border and vacuole cells in chick inner ear. J Comp Neurol 318:64-82.

Richardson GP, Bartolami S, Russell IJ (1990) Identification of a 275 $\mathrm{kDa}$ protein associated with the apical surfaces of sensory hair cells in the avian inner ear. J Cell Biol 110:1055-1066.

Roe TY, Reynolds TC, Yu G, Brown PO (1993) Integration of murine leukemia virus DNA depends on mitosis. EMBO J 12:2099-2108.

Ryals BM, Rubel EW (1988) Hair cell regeneration after acoustic trauma in adult coturnix quail. Science 240:1774-1776.

Ryder EF, Cepko CL (1994) Migration patterns of clonally related granule cells and their progenitors in the developing chick cerebellum. Neuron 12:1011-1029.

Stoker AW, Bissell MJ (1988) Development of avian sarcoma and leukosis virus-based vector-packaging cell lines. J Virol 62:1008-1015.

Stone JS, Cotanche DA (1994) Identification of the timing of S phase and the patterns of cell proliferation during hair cell regeneration in the chick cochlea. J Comp Neurol 341:50-67.

Stone JS, Leano SG, Baker LP, Rubel EW (1996) Hair cell differentiation in chick cochlear epithelium after aminoglycoside toxicity: in vivo and in vitro observations. J Neurosci 16:6157-6174.

Turner DL, Cepko CL (1987) A common progenitor for neurons and glia persists in rat retina late in development. Nature 328:131-136.

Turner DL, Snyder EY, Cepko CL (1990) Lineage-independent determination of cell type in the embryonic mouse retina. Neuron 4:833-845.

Warchol, ME, Corwin, JT (1996) Regenerative proliferation in organ cultures of the avian cochlea: identification of the initial progenitors and determination of the latency of the proliferative response. J Neurosci 16:5466-5477.

Wetts R, Fraser SE (1988) Multipotent precursors can give rise to all major cell types of the frog retina. Science 239:1142-1145.

Whitfield T, Haddon C, Lewis J (1997) Intercellular signals and cell-fate choices in developing inner ear: origin of global and fine-grained pattern. Semin Cell Dev Biol 8:239-247.

Zheng JL, Gao W-Q (1997) Analysis of rat vestibular hair cell development and regeneration using calretinin as an early marker. J Neurosci $17: 8270-8282$. 